\title{
Up-regulation of inhibitors of DNA binding/differentiation gene during alendronate-induced osteoblast differentiation
}

\author{
Ae Ra Kang $\cdot$ Young Rim Oh $\cdot$ Heung Yeol Kim $\cdot$ Min Jung Park \\ Bo Sun Joo - Won Jun Choi · Ji Young Lee • Min Hyung Jung • Yong Il Ji • \\ Jong Soon Choi
}

Received: 8 August 2011/Accepted: 4 November 2011/Published online: 25 November 2011

(C) The Author(s) 2011. This article is published with open access at Springerlink.com

\begin{abstract}
Purpose To investigate the effect of alendronate on the expression of $I d$ genes in osteoblast differentiation.

Methods C2C12 cells were treated with alendronate for various concentrations and time periods. For evaluation of alendronate-induced osteoblast differentiation in $\mathrm{C} 2 \mathrm{C} 12$ cells, alkaline phosphatase (ALP) activity was measured. The expression of osteoblast differentiation markers such as ALP, type-1 collagen ( $\mathrm{Col} 1)$, and osteocalcin $(\mathrm{OCN})$,
\end{abstract}

A. R. Kang · Y. R. Oh · H. Y. Kim

Department of Obstetrics and Gynecology, College of Medicine, Kosin University, Busan, Republic of Korea

M. J. Park · B. S. Joo

Center for Reproductive Medicine and Infertility,

Good Moonhwa Hospital, Busan, Republic of Korea

W. J. Choi

Department of Obstetrics and Gynecology, School of Medicine, Gyeongsang National University, Jinju, Republic of Korea

J. Y. Lee

Department of Obstetrics and Gynecology, School of Medicine, Konkuk University, Seoul, Republic of Korea

M. H. Jung

Department of Obstetrics and Gynecology, School of Medicine, Kyung Hee University, Seoul, Republic of Korea

Y. I. Ji

Department of Obstetrics and Gynecology, School of Medicine, Inje University, Haeundaepaik Hospital, Busan, Republic of Korea

J. S. Choi $(\bowtie)$

Department of Family Medicine, College of Medicine,

Kosin University, Busan, Republic of Korea

e-mail: ds5ppp@hotmail.com and the expression of Id- 1 and Id-2 were measured by RTPCR. In order to understand the mechanism underlying the regulation of $I d$ genes, the promoter region of the $I d-1$ gene was identified. Database analysis of the promoter region for $I d-1$ using known consensus sequences identified several putative response elements, including CCAAT/enhancerbinding protein beta $(\mathrm{C} / \mathrm{EBP} \beta)$.

Results Alendronate treatment significantly increased not only ALP activity but also the expression of ALP, Col 1, and OCN, Id-1 and Id-2. C/EBP $\beta$ and alendronate cooperatively increased the promoter activity and expression of Id-1.

Conclusions These results suggest that $\mathrm{C} / \mathrm{EBP} \beta$-mediated $I d-1$ transcriptional activation may regulate alendronateinduced osteoblast differentiation of $\mathrm{C} 2 \mathrm{C} 12$ cells.

Keywords Alendronate $\cdot$ Osteoblasts $\cdot$ Osteoporosis

\section{Introduction}

Bisphosphonates are commonly used in the treatment and prevention of excessive bone resorption diseases such as post-menopausal osteoporosis due to their inhibitory osteoclast activity [1]. However, there has been increasing evidence that a variety of bisphosphonates can also stimulate osteoblast proliferation, differentiation, and bone formation, as well as inhibit osteoblast apoptosis [2-5].

The process of osteoblast differentiation is under various central and local controls including bone morphogenetic proteins (BMP), Indian hedgehog, fibroblast growth factor2 (FGF2), Wnt, parathyroid hormone, and leptin [6-9]. Further, studies have proposed several possible mechanisms governing bisphosphonate-mediated osteoblast differentiation $[10,11]$. 
Inhibitors of DNA binding/differentiation (Id), which are inhibitory helix-loop-helix (HLH) transcription factors, have been reported to affect the balance between cell growth and differentiation of osteoblast [12, 13]. Further, it has been indicated that a balanced regulation of $I d$ gene expression plays an important role in promoting proliferation at the early stage of osteoblast lineage-specific differentiation [12]. Bone morphogenetic proteins (BMPs) are known to convert the differentiation pathway of myoblastic cell lines into osteoblast lineages and stimulate osteoblast lineage-specific differentiation of mesenchymal stem cells by controlling expression of inhibitors of DNA binding/ differentiation (Ids) [6, 12].

Alendronate, which is a well-known third-generation bisphosphonate, enhances the expression of BMP-2 and osteoblast maturation [4]. However, no studies to date have evaluated the possible role of Ids in alendronate-induced osteoblast differentiation. Therefore, the purpose of this study was to investigate the expression of Ids genes in alendronate-induced osteoblast differentiation using myoblastic C2C12 cells.

\section{Materials and methods}

\section{Cell culture and alendronate treatment}

$\mathrm{C} 2 \mathrm{C} 12$ cells were maintained under $5 \% \mathrm{CO}_{2}$ at $37^{\circ} \mathrm{C}$ in growth medium, consisting of Dulbecco's modified Eagle's medium (DMEM; Gibco BRL, Grand Island, NY, USA) supplemented with $10 \%$ fetal bovine serum (FBS; Gibco BRL) and $1 \%$ penicillin-streptomycin (PS; Gibco BRL). The medium was changed every 2 or 3 days, and the cells were cultured in serum-free DMEM with various concentrations of alendronate.

\section{MTT (3-dimethylthiazol-2,5-diphenyltetrazolium} bromide) assay

C2C12 cells were plated at a density of $2 \times 10^{4}$ cells in 24-well plates. After overnight incubation, alendronate was added to final concentrations ranging from $10^{-3}$ to $10^{-9} \mathrm{M}$ for 24,48 , and $72 \mathrm{~h}$. At the time points indicated, the cells were washed with PBS, and $100 \mu \mathrm{l}$ of MTT stock solution ( $5 \mathrm{mg} / \mathrm{ml}$, Sigma, St. Louis, MO, USA) was added to each culture medium and continued for $1 \mathrm{~h}$ at $37^{\circ} \mathrm{C}$. This time period permitted the cellular conversion of MTT to an insoluble form. Then, the cells were lysed, and the formazan crystals were dissolved in DMSO at room temperature for $5 \mathrm{~min}$, after which $100 \mu \mathrm{l}$ of supernatant was transferred to the wells of a 96-well microplate. Colorimetric changes were subsequently quantified using a microplate reader at a wavelength of $540 \mathrm{~nm}$ (Spectra MAX 250, Molecular Devices Co., USA).

Alkaline phosphatase activity assay

To mediate the differentiation of $\mathrm{C} 2 \mathrm{C} 12$ cells to osteoblasts, C2C12 cells were first plated at a density of $2 \times 10^{4}$ cells in 24-well plates. After overnight incubation, the cells were cultured in serum-free DMEM with or without alendronate at concentrations ranging from $10^{-4}$ to $10^{-9} \mathrm{M}$ for 24,48 , and $72 \mathrm{~h}$. At the time points indicated, the cells were washed with ice-cold phosphate-buffered saline (PBS), lysed in 1\% Triton X-100 (Sigma), and subjected to three freeze-thaw cycles. After centrifugation $(4,000 \mathrm{~g})$ of the lysates, the cellular debris were removed and supernatants were collected. The collected supernatants were then mixed with a colorless $p$-nitrophenyl phosphate (Sigma) according to the manufacturer's protocol, and the conversion of colored $p$-nitrophenol was measured using a microplate reader at a wavelength of $405 \mathrm{~nm}$.

\section{RNA preparation and RT-PCR}

Quantitative RT-PCR conditions were set for analysis of three osteoblast differentiation markers, namely, alkaline phosphatase activity (ALP), type-1 collagen (Col 1) and osteocaclin (OCN). Total RNA was extracted using Trizol reagent (Invitrogen, Carlsbad, CA, USA) according to the manufacturer's protocol. Complementary DNA was synthesized from $5 \mu \mathrm{g}$ of total RNA with AMV Reverse Transcriptase (Promega, Madison, WI, USA) using random hexamers (Bioneer, Daejon, Korea) at $42^{\circ} \mathrm{C}$ for $1 \mathrm{~h}$. Template cDNA was subjected to PCR amplification using genespecific sense and antisense primers (Table 1). The cDNAs were amplified by PCR under the following conditions: 28-35 cycles of denaturation at $95^{\circ} \mathrm{C}$ for $30 \mathrm{~s}$, annealing at $58^{\circ} \mathrm{C}$ for $30 \mathrm{~s}$, and extension at $72^{\circ} \mathrm{C}$ for $30 \mathrm{~s}$ in a thermal cycler. PCR products were visualized by electrophoresis on $1.2 \%$ agarose gels. The PCR bands were quantified and normalized relative to the control band with Image J, version $1.35 \mathrm{~d}$ (National Institutes of Health Image software).

Transient transfection of $\mathrm{C} 2 \mathrm{C} 12$ cells and luciferase activity assay

C2C12 cells were plated in 24-well plates 1 day before transfection. The cells were transiently transfected with a reporter vector and $\beta$-galactosidase expression plasmid, along with each indicated expression plasmids using Jetpei (polyplus-transfection, Illkirch, France); addition of pcDNA3.1/ HisC plasmid DNA was added to maintain equal amounts of DNA per transfection. After $48 \mathrm{~h}$ post-transfection, the cells 
Table 1 Primers sequences used for PCR amplification

\begin{tabular}{|c|c|}
\hline Gene & Primer sequence \\
\hline \multicolumn{2}{|c|}{ Alkaline phosphatase (ALP) } \\
\hline Forward & $5^{\prime}$ - TCATGTTCCTGGGAGATTGGGTATG -3' \\
\hline Reverse & $5^{\prime}$ - GCATTAGCTGATAGGCGATGTCC - $3^{\prime}$ \\
\hline \multicolumn{2}{|c|}{ Type I Collagen (Col 1) } \\
\hline Forward & $5^{\prime}$ - CAAGGGTGAGACAGGGCAAC $-3^{\prime}$ \\
\hline Reverse & $5^{\prime}$ - CTCGAACTGGAATCCATCGGT - $3^{\prime}$ \\
\hline \multicolumn{2}{|c|}{ Osteocalcin $(\mathrm{OCN})$} \\
\hline Forward & 5'- CTGAGTCTGACAAAGCCTTC - $3^{\prime}$ \\
\hline Reverse & $5^{\prime}$ - GCTGCTGTGACATCCATACTTGC -3' \\
\hline \multicolumn{2}{|c|}{ Cathepsin K (CTSK) } \\
\hline Forward & $5^{\prime}$ - GGGCCAGGATGAAAGTTGTA - $3^{\prime}$ \\
\hline Reverse & $5^{\prime}$ - CCGAGCCAAGAGAGCATATC - 3' \\
\hline \multicolumn{2}{|c|}{ Inhibitor of differentiation-1 (Id1) } \\
\hline Forward & 5'- CTGCTCTACGACATGAACGGCTG - -3' \\
\hline Reverse & $5^{\prime}$ - CGGATTCCGAGTTCAGCTCCAAC - 3' \\
\hline \multicolumn{2}{|c|}{ Inhibitor of differentiation-2 (Id2) } \\
\hline Forward & $5^{\prime}$ - GGGCCAGGATGAAAGTTGTA - $3^{\prime}$ \\
\hline Reverse & $5^{\prime}$ - CCGAGCCAAGAGAGCATATC - $3^{\prime}$ \\
\hline \multicolumn{2}{|l|}{$\beta$-Actin } \\
\hline Forward & $5^{\prime}$ - GACTACCTCATGAAGATC - $3^{\prime}$ \\
\hline Reverse & $5^{\prime}$ - GATCCACATCTGCTGGAA - $3^{\prime}$ \\
\hline
\end{tabular}

were rinsed with ice-cold PBS and lysed with $1 \times$ Cell Culture Lysis Buffer (Promega). Luciferase activity was determined using an analytical-luminescence luminometer according to the manufacturer's instructions. Luciferase activity was normalized for transfection efficiency according to the corresponding $\beta$-galactosidase activity.

\section{Statistical analysis}

All experiments were performed at least five times, and the data are expressed as the mean $\pm \mathrm{SD}$. The statistical significance of differences between the experiment and control groups were evaluated by student's $t$ test and one-way ANOVA. Values of $P<0.05$ were considered to be statistically significant.

\section{Results}

Effect of alendronate on cell viability and ALP activity in $\mathrm{C} 2 \mathrm{C} 12$ cells

There were no significant changes in the percentage of viable cells at concentrations of alendronate ranging from $10^{-4}$ to $10^{-9} \mathrm{M}$ up to $72 \mathrm{~h}$. However, cell viability was significantly decreased with a higher dose $\left(10^{-3} \mathrm{M}\right)$ of alendronate (Fig. 1). Based on the results of this viability

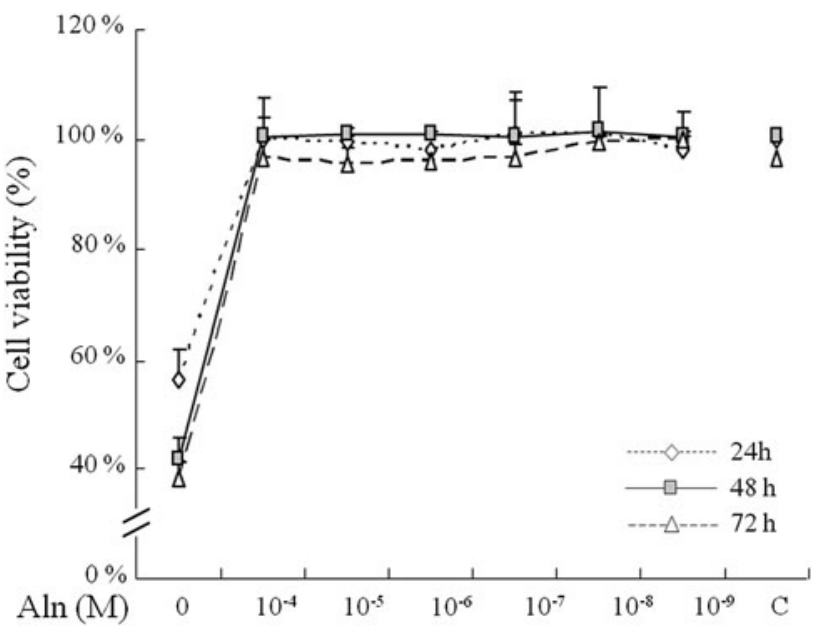

Fig. 1 Effect of alendronate on cell viability. C2C12 cells were treated with alendronate using concentrations ranging from $10^{-3}$ to $10^{-9} \mathrm{M}$ for 24,48 , and $72 \mathrm{~h}$. Cell viability was determined using MTT assay (mean $\pm \mathrm{SD}, n=5$ )

assay, we assessed osteoblast differentiation by measuring ALP activity at different concentrations of alendronate ranging from $10^{-4}$ to $10^{-9} \mathrm{M}$. Alendronate-induced osteoblast differentiation of $\mathrm{C} 2 \mathrm{C} 12$ cells increased nearly twofold as determined by ALP activity in response to all concentrations of alendronate after $24 \mathrm{~h}$ of treatment compared to the control group. Furthermore, elevated ALP activity was also observed at alendronate concentrations from $10^{-6}$ to $10^{-8} \mathrm{M}$ for $48 \mathrm{~h}$ (Fig. 2). Together, these results suggested that alendronate might play a role in the early stage of $\mathrm{C} 2 \mathrm{C} 12$ cell differentiation into osteoblasts.

Effect of alendronate on osteoblast-specific gene expression

To clarify the potential role of alendronate in osteoblast differentiation of $\mathrm{C} 2 \mathrm{C} 12$ cells, we next examined the expression of three osteoblast-specific genes, namely, ALP, Col 1, and OCN. For these experiments, $\mathrm{C} 2 \mathrm{C} 12$ cells were treated with alendronate at concentrations ranging from $10^{-6}$ to $10^{-8} \mathrm{M}$ for $48 \mathrm{~h}$ based on the ALP activity assays. Treatment with alendronate treatment resulted in a significant increase in expression of ALP, Col 1, and OCN compared to controls. Further, the expression levels of ALP and Col 1 peaked at an alendronate concentration of $10^{-8} \mathrm{M}$ (Fig. 3a, b).

Following the treatment with $10^{-8} \mathrm{M}$ of alendronate, the concentration of which resulted in peak levels of ALP and $\mathrm{Col} 1, \mathrm{C} 2 \mathrm{C} 12$ cells were treated with alendronate of $10^{-8} \mathrm{M}$ for 24,48 , and $72 \mathrm{~h}$ to evaluate the effect of alendronate according to treatment time. The time course study indicated that the expression of ALP and Col 1 was significantly increased until $48 \mathrm{~h}$, but decreased thereafter. Likewise, the expression of OCN was significantly increased from $72 \mathrm{~h}$ (Fig. 3c, d). These results indicate the 


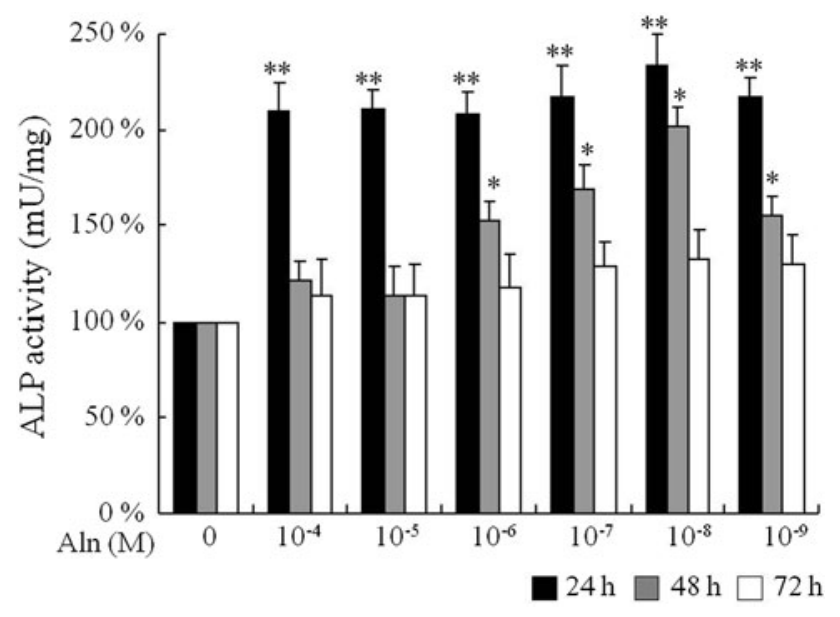

Fig. 2 Effect of alendronate-induced osteoblast differentiation of $\mathrm{C} 2 \mathrm{C} 12$ cells. Cells were treated with alendronate at different concentration and time periods as indicated. The ALP activity was measured at $405 \mathrm{~nm}$. The experiment was repeated five times and performed with triple samples. $* P<0.05$ and $* * P<0.01$ compared (vs. control)

presence of different expression patterns for each osteoblast-specific marker according to the concentration and duration of alendronate treatment in alendronate-induced osteoblast differentiation.

Expression of Id-1 and Id-2 during alendronate-induced osteoblast differentiation of $\mathrm{C} 2 \mathrm{C} 12$ cells

Next, we carried out expression analysis of $I d$ genes in alendronate-induced osteoblast differentiated $\mathrm{C} 2 \mathrm{C} 12$ cells. Alendronate treatment significantly stimulated Id-1 and Id2 mRNA expression at all treated doses compared to controls (Fig. 4a, b).

We further examined the expression of Id- 1 and Id-2 at 24,48 , and $72 \mathrm{~h}$ after treatment with alendronate at concentration of $10^{-8} \mathrm{M}$ based on above data. Alendronate treatment exhibited a significant increase in the expression of both $I d-1$ and $I d-2$ genes compared to controls. The expression of Id-1 was significantly increased after alendronate treatment at all time-periods, although levels peaked at $48 \mathrm{~h}$. Similarly, Id-2 expression was significantly up-regulated until $48 \mathrm{~h}$, but was undetectable thereafter (Fig. 4c, d). These results indicated that $I d-1$ and $I d-2$ might be involved in alendronate-induced early stage of osteoblast differentiation in $\mathrm{C} 2 \mathrm{C} 12$ cells.

Effect of alendronate on C/EBP $\beta$-mediated Id-1 transcriptional activity

In order to investigate the transcriptional mechanism by which alendronate regulates the expression of Id-1, we examined the promoter region of the $I d-1$ gene using the GeneBank database to search for known consensus sequences in the $I d-1$ promoter. Several putative response elements, such as Nuclear factor-kappaB (NF-kB), acute myelogenous leukemia1/runt-related transcription factor1 (AML1/ RUNX1), CDX, cAMP response element binding (CREB), and CCAAT/enhancer-binding protein beta $(\mathrm{C} / \mathrm{EBP} \beta)$ were detected in the $I d-1$ promoter region. $\mathrm{C} 2 \mathrm{C} 12$ cells were transiently co-transfected with $I d-1$-luciferase reporter vector along with expression vector encoding these response elements or empty vector. After transfection, $I d-1$ promoter activity was significantly increased in CREB or C/EBP $\beta$ overexpressing cells compared to controls. Especially, $\mathrm{C} / \mathrm{EBP} \beta$ induced approximately 4.3 -fold increase in $I d-1$ promoter activity (Fig. 5a). To investigate whether $\mathrm{C} / \mathrm{EBP} \beta$ regulates the expression of Id-1 stimulated by alendronate, $\mathrm{C} 2 \mathrm{C} 12$ cells were co-transfected with the $I d-l$ luciferase reporter plasmid along with $\mathrm{C} / \mathrm{EBP} \beta$-expression vector, followed by alendronate treatment. Overexpression of $\mathrm{C} / \mathrm{EBP} \beta$ and alendronate treatment synergistically increased $I d-1$ promoter activity (Fig. $5 \mathrm{~b}$ ).

In order to determine further the effect of alendronateinduced osteoblast differentiation on $\mathrm{C} / \mathrm{EBP} \beta$-mediated Id1 expression, we transiently transfected the $\mathrm{C} / \mathrm{EBP} \beta$ expression vector or empty vector as a control in the absence or presence of alendronate. Consistent with the results of the reporter assay, expression of Id- 1 was slightly increased in the presence of $\mathrm{C} / \mathrm{EBP} \beta$. Overexpression of $\mathrm{C} / \mathrm{EBP} \beta$ and alendronate markedly increased ALP expression in $\mathrm{C} 2 \mathrm{C} 12$ cells (Fig. 5c, d). These results indicated that alendronate increased ALP expression, a marker of early osteoblast differentiation, and this increased expression might be associated with increased $I d-1$ expression through transcriptional regulation of $\mathrm{C} / \mathrm{EBP} \beta$.

\section{Discussion}

The present study demonstrated that alendronate induced osteoblast differentiation of the $\mathrm{C} 2 \mathrm{C} 12$ myoblastic cell line. This study also revealed an interesting finding whereby alendronate stimulated the expression of $I d$ genes, which was accompanied by up-regulation of $\mathrm{C} / \mathrm{EBP} \beta$ mediated $I d-1$ expression.

The expression of $I d$ genes was significantly increased in the early stage of BMP stimulated-osteoblast differentiation [12, 14]. Especially, BMP-2 stimulates not only various osteoblast-specific differentiation markers, but also converts the differentiation pathway of $\mathrm{C} 2 \mathrm{C} 12$ myoblasts into the osteoblast lineage $[6,8,12]$. Im et al [4] reported that alendronate enhances the expression of BMP-2 in osteoblasts. Such previous results imply that alendronate might stimulate osteoblast differentiation by regulation of 
A

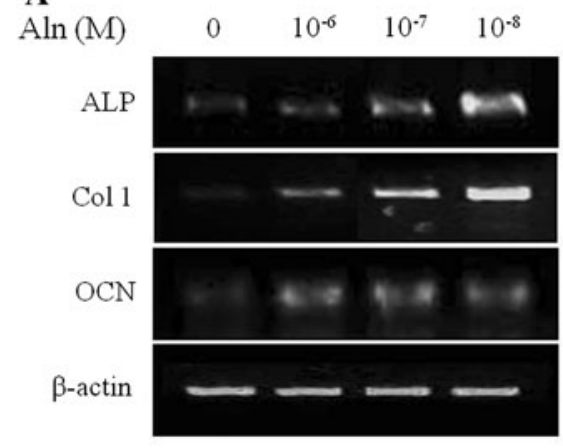

C

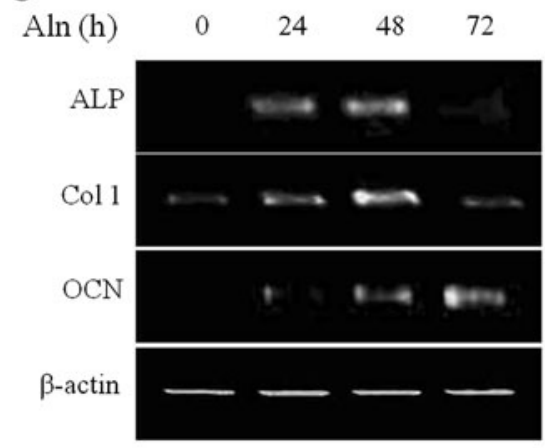

B
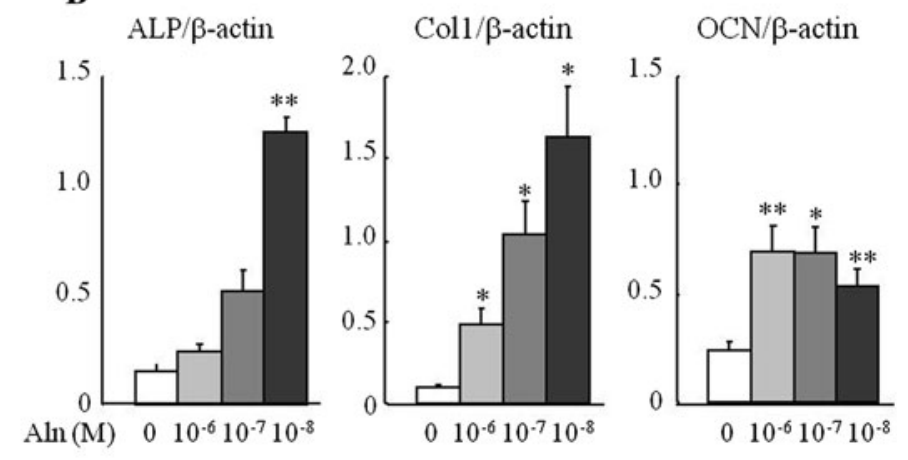

D
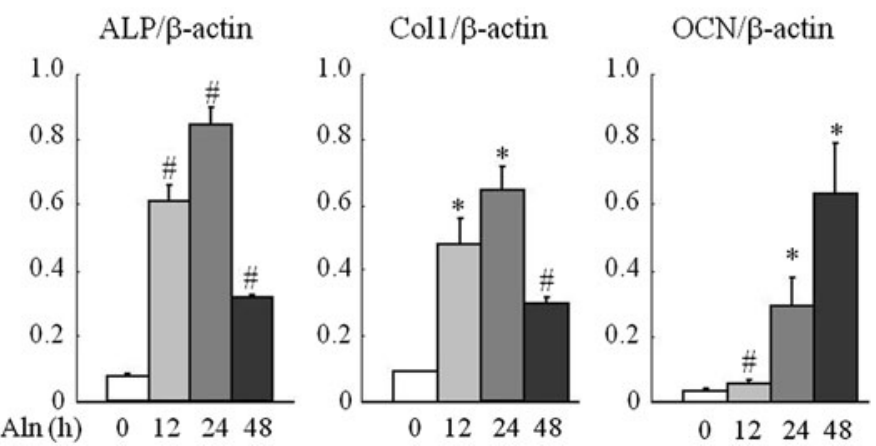

Fig. 3 Effect of alendronate on the expression of osteoblast differentiation markers. Osteoblast differentiation was determined by RTPCR analysis for the expression of ALP, and Col 1. C2C12 cells were treated with alendronate at concentrations ranged from $10^{-6}$ to $10^{-8} \mathrm{M}$ for $48 \mathrm{~h}$ (a) and at $10^{-8} \mathrm{M}$ concentration for different time periods $(24,48$, and $72 \mathrm{~h})$ (c). Data are from a representative experiment. b, d The amount of each mRNA was normalized to that of $\beta$-actin mRNA. Quantitative data are means \pm SD from six independent experiments. ${ }^{*} P<0.05$, ${ }^{*} * P<0.01$ and ${ }^{\#} P<0.005$ (vs. control)
A

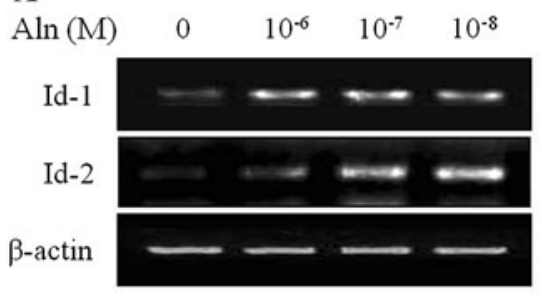

C

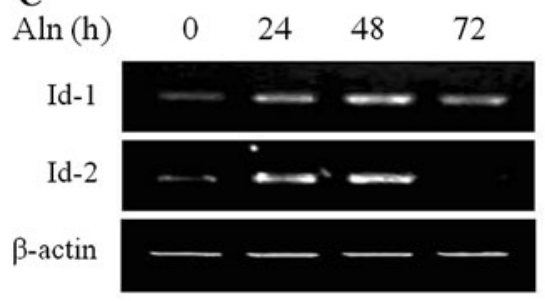

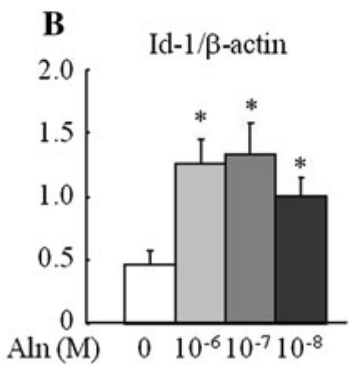
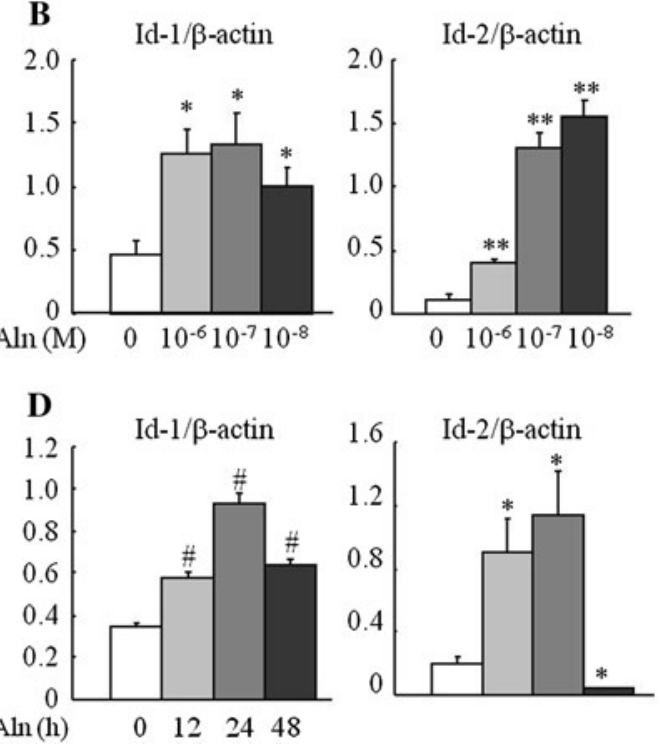

Fig. 4 Expression of $I d-1$ and $I d-2$ genes during alendronate-induced osteoblast differentiation. $\mathrm{C} 2 \mathrm{C} 12$ cells were treated with alendronate at concentrations ranging from $10^{-6}$ to $10^{-8} \mathrm{M}$ for $48 \mathrm{~h}$ (a) and at $10^{-8} \mathrm{M}$ concentration for different time periods $(24,48$, and $72 \mathrm{~h}$ ) (c). At the indicated time after alendronate treatment, the expression of $I d-1$ and $I d-2$ mRNA was analyzed by RT-PCR. Data are from a representative experiment. b, $\mathbf{d}$ The amount of Id-1 and Id-2 mRNA was normalized btoy that of $\beta$-actin mRNA. Quantitative data are mean $\pm \mathrm{SD}$ from six independent experiments. $* P<0.05$, ** $P<0.01$ and ${ }^{\#} P<0.005$ (vs. control) 

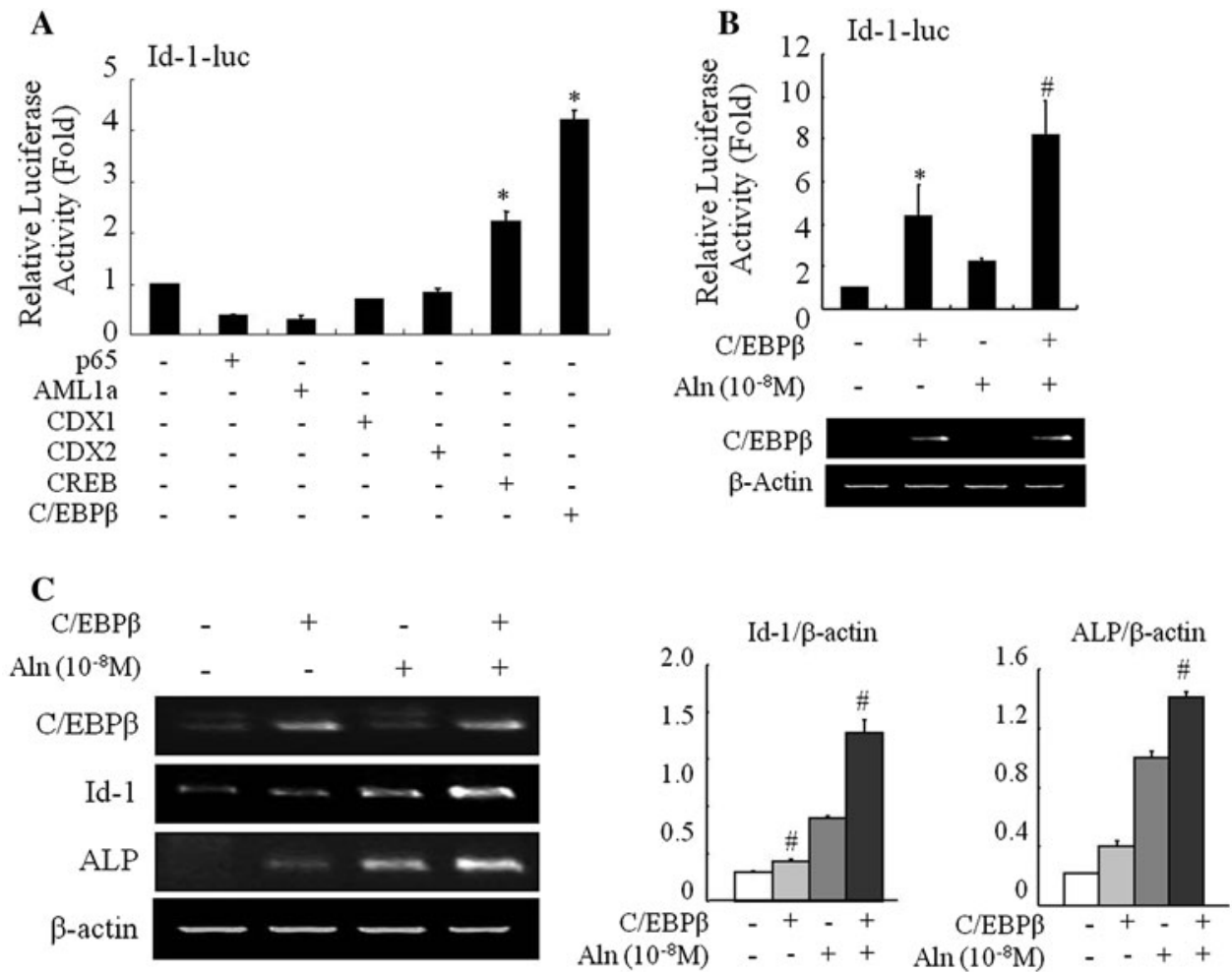

Fig. 5 Effect of alendronate on $I d-1$ transactivation. a Determination of response elements in the $I d-1$ promoter region. $\mathrm{C} 2 \mathrm{C} 12$ cells were transiently transfected with $I d$-1-luciferase reporter vector along with expression vector encoding p65, AML1a, CDX1, CDX2, CREB or $\mathrm{C} / \mathrm{EBP} \beta$, or empty vector as control. After $48 \mathrm{~h}$ of transfection, cell lysates were assayed for luciferase activity. Results are the average of three independent experiments, with fold induction referring to the level observed divided by the reporter activity alone. $*<0.05$ (vs. empty vector). $\mathbf{b}$ The effect of alendronate on C/EBP $\beta$-mediated $I d-1$ transactivation. $\mathrm{C} 2 \mathrm{C} 12$ cells were transiently transfected with $I d-1$ luciferase reporter plasmid along with an expression vector encoding for $\mathrm{C} / \mathrm{EBP} \beta$ or an empty vector and then treated with $10^{-8} \mathrm{M}$ of

Id gene expression. In our study, the expression of Id- 1 and Id-2 peaked within $48 \mathrm{~h}$ of alendronate-induced osteoblast differentiation of $\mathrm{C} 2 \mathrm{C} 12$ cells. In this respect, our results suggest the possibility that alendronate might be associated with the BMP-2 signaling pathway to induce osteoblast differentiation. However, further study is needed to evaluate this hypothesis.

C/EBPs are critical for normal cellular differentiation and metabolic functions in various tissues. Especially, $\mathrm{C} / \mathrm{EBP} \beta$ is expressed in osteoblastic cells and up-regulated during osteoblast differentiation [15]. This result led us to the hypothesis that increased expression of Id-1 by alendronate might be mediated via a $\mathrm{C} / \mathrm{EBP} \beta$-binding element contained within the $I d-1$ promoter. The present study showed that overexpression of $\mathrm{C} / \mathrm{EBP} \beta$ and alendronate treatment synergistically increased the promoter activity and expression of Id-1. To the best of our knowledge, this is the first study to report a potential role of Id-1 alendronate. After $48 \mathrm{~h}$ of transfection, cell lysates were assayed for luciferase activity (upper panel) and subjected for expression of the indicated transcripts by RT-PCR (lower panel). Bars represent the mean \pm SD of six independent experiments with duplication.* $<0.05$ (vs. empty vector) and ${ }^{\#}<0.005$ (vs. C/EBP $\beta$ alone). c C2C12 cells were transiently transfected with expression vector pcDNA3 alone (empty vector) or containing $\mathrm{C} / \mathrm{EBP} \beta$ expression vector and then treated with $10^{-8} \mathrm{M}$ of alendronate. The Id-1 and ALP mRNA levels were detected via RT-PCR (left panel). The amount of each mRNA was normalized to that of $\beta$-actin mRNA (right panel). Experiments were performed at least five times; representative experiments are shown. ${ }^{\#}<0.005$ (vs. control)

and $\mathrm{C} / \mathrm{EBP} \beta$ in alendronate-induced differentiation of $\mathrm{C} 2 \mathrm{C} 12$ cells into osteoblasts.

We demonstrated the presence of differential patterns of increased expression of Id-1 and Id-2 expression by alendronate. This finding was not unexpected, as $I d-1$ is known to be a direct target gene for BMPs that strongly activate its promoter [16-19]. Although the exact mechanism is unclear, induction of Id-2 in alendronate-induced osteoblast differentiation of $\mathrm{C} 2 \mathrm{C} 12$ cells might involve indirect targeting of BMP-signaling.

In their study of alendronate localization in rat bones, Sato et al. [20] reported that alendronate was accumulated in the resorption space at a maximum concentration of $10^{-3} \mathrm{M}$ after alendronate injection. Consistent with the results of our study, Garcia-Moreno et al. [2] showed that no viable cells were detected with alendronate concentrations of $10^{-3} \mathrm{M}$ or higher, while at lower concentrations of alendronate, there were no significant effects compared to 
controls. The effects of alendronate have been shown to be greatly dose-dependent in a rat model of arthritis; high doses of alendronate have an adverse effect on osteoblast Function [20]. This dose dependent effect of alendronate was also supported by previous studies showing that bisphosphonates increase bone marrow-derived preosteoblastic cell proliferation and inhibit the apoptosis of osteocytes and osteoblasts at low concentrations [3, 21]. This dosedependent effect was also observed in our present study, which showed that low concentrations of alendronate stimulated early signs of osteoblast differentiation such as increased ALP activity. Thus, it can be concluded that low doses of alendronate may stimulate osteoblast differentiation of $\mathrm{C} 2 \mathrm{C} 12$ cells, whereas a higher dose may inhibit osteoblast function.

The present study shows that the expression pattern of each osteoblast marker differed according to the time periods of alendronate treatment; ALP and Col1 expression increased up to $48 \mathrm{~h}$, but decreased thereafter, whereas OCN expression was increased only after $48 \mathrm{~h}$. This result may be attributable to the fact that each osteoblast differentiation marker reflects different stages of differentiation and thus different osteoblastic activity; ALP and Col 1 are early markers of osteoblast differentiation, while OCN appears late, concomitant with mineralization [6, 22].

In this present study, gene expression at the mRNA level was evaluated but expression at the protein level was not. This would be the limitation of this study. Despite the limitations of our study, the presented data may contribute to the understanding of the mechanism of alendronateinduced osteoblast differentiation, suggesting that alendronate might initially promote the gene expression of $\mathrm{C} / \mathrm{EBP} \beta$-mediated Id- 1 and trigger the sequential activation of osteoblast-specific genes such as ALP, Col 1, and OCN.

Differentiation processes are associated with morphological changes. Nakashima et al. [23] reported that the transformed cell (Wnt3a-C2C12) exhibited a distinct morphological change along with osteoblast gene expression. However, our present study could not observe morphological changes of the $\mathrm{C} 2 \mathrm{C} 12$ cells during the 3 days of culture. This may be due to short culture duration. Nakashima et al. cultured transformed (Wnt3a-C2C12) cells for 3-9 days, and morphological changes were found at the 6th day of culture. Therefore, to warrant our data, further studies on the observation of morphological changes at the protein level are needed, using stable Id-1 transformed $\mathrm{C} 2 \mathrm{C} 12$ cells for long-term culture.

In conclusion, the present study shows that the expression of $I d-1$ and $I d-2$ genes was stimulated in alendronateinduced differentiation of $\mathrm{C} 2 \mathrm{C} 12$ cells myoblasts into osteoblast lineage. In addition, this study suggests that the increased expression of $I d-I$ in alendronate-induced osteoblast differentiation may be regulated by $\mathrm{C} / \mathrm{EBP} \beta$.
Acknowledgments We thank Dr. Cheong JH (Pusan National University) for providing $I d$-1-luciferase reporter plasmid and $\mathrm{C} / \mathrm{EBP} \beta$ plasmid.

\section{Conflict of interest None.}

Open Access This article is distributed under the terms of the Creative Commons Attribution Noncommercial License which permits any noncommercial use, distribution, and reproduction in any medium, provided the original author(s) and source are credited.

\section{References}

1. Russell RG (2006) Bisphosphonates: from bench to bedside. Ann NY Acad Sci 1068:367-401

2. Garcia-Moreno C, Serrano S, Nacher M, Farre M, Diez A, Marinoso ML, Carbonell J, Mellibovsky L, Nogues X, Ballester J, Aubia J (1998) Effect of alendronate on cultured normal human osteoblasts. Bone 22(3):233-239

3. Reinholz GG, Getz B, Pederson L, Sanders ES, Subramaniam M, Ingle JN, Spelsberg TC (2000) Bisphosphonates directly regulate cell proliferation, differentiation, and gene expression in human osteoblasts. Cancer Res 60(21):6001-6007

4. Im GI, Qureshi SA, Kenney J, Rubash HE, Shanbhag AS (2004) Osteoblast proliferation and maturation by bisphosphonates. Biomaterials 25(18):4105-4115

5. Plotkin LI, Weinstein RS, Parfitt AM, Roberson PK, Manolagas SC, Bellido T (1999) Prevention of osteocyte and osteoblast apoptosis by bisphosphonates and calcitonin. J Clin Invest 104(10):1363-1374

6. Katagiri T, Yamaguchi A, Komaki M, Abe E, Takahashi N, Ikeda T, Rosen V, Wozney JM, Fujisawa-Sehara A, Suda T (1994) Bone morphogenetic protein-2 converts the differentiation pathway of $\mathrm{C} 2 \mathrm{C} 12$ myoblasts into the osteoblast lineage. J Cell Biol 127(6 Pt 1):1755-1766

7. Aubin JE (1998) Bone stem cells. J Cell Biochem Suppl 30-31:73-82

8. Canalis E, Economides AN, Gazzerro E (2003) Bone morphogenetic proteins, their antagonists, and the skeleton. Endocr Rev 24(2):218-235

9. Malaval L, Liu F, Roche P, Aubin JE (1999) Kinetics of osteoprogenitor proliferation and osteoblast differentiation in vitro. J Cell Biochem 74(4):616-627

10. Fu L, Tang T, Miao Y, Zhang S, Qu Z, Dai K (2008) Stimulation of osteogenic differentiation and inhibition of adipogenic differentiation in bone marrow stromal cells by alendronate via ERK and JNK activation. Bone 43(1):40-47

11. Xiong Y, Yang HJ, Feng J, Shi ZL, Wu LD (2009) Effects of alendronate on the proliferation and osteogenic differentiation of MG-63 cells. J Int Med Res 37(2):407-416

12. Peng Y, Kang Q, Luo Q, Jiang W, Si W, Liu BA, Luu HH, Park JK, Li X, Luo J, Montag AG, Haydon RC, He TC (2004) Inhibitor of DNA binding/differentiation helix-loop-helix proteins mediate bone morphogenetic protein-induced osteoblast differentiation of mesenchymal stem cells. J Biol Chem 279(31):32941-32949

13. Maeda Y, Tsuji K, Nifuji A, Noda M (2004) Inhibitory helixloop-helix transcription factors Id1/Id3 promote bone formation in vivo. J Cell Biochem 93(2):337-344

14. Miyazono K, Miyazawa K (2002) Id: a target of BMP signaling. Sci STKE 2002(151):pe40

15. Tominaga H, Maeda S, Hayashi M, Takeda S, Akira S, Komiya S, Nakamura T, Akiyama H, Imamura T (2008) CCAAT/ 
enhancer-binding protein beta promotes osteoblast differentiation by enhancing Runx 2 activity with ATF4. Mol Biol Cell 19(12):5373-5386

16. Kreider BL, Benezra R, Rovera G, Kadesch T (1992) Inhibition of myeloid differentiation by the helix-loop-helix protein Id. Science 255(5052):1700-1702

17. Ruzinova MB, Benezra R (2003) Id proteins in development, cell cycle and cancer. Trends Cell Biol 13(8):410-418

18. Lopez-Rovira T, Chalaux E, Massague J, Rosa JL, Ventura F (2002) Direct binding of Smad1 and Smad4 to two distinct motifs mediates bone morphogenetic protein-specific transcriptional activation of Id1 gene. J Biol Chem 277(5):3176-3185

19. Korchynskyi O, ten Dijke P (2002) Identification and functional characterization of distinct critically important bone morphogenetic protein-specific response elements in the Id1 promoter. J Biol Chem 277(7):4883-4891
20. Sato M, Grasser W, Endo N, Akins R, Simmons H, Thompson DD, Golub E, Rodan GA (1991) Bisphosphonate action Alendronate localization in rat bone and effects on osteoclast ultrastructure. J Clin Invest 88(6):2095-2105

21. Klein BY, Ben-Bassat H, Breuer E, Solomon V, Golomb G (1998) Structurally different bisphosphonates exert opposing effects on alkaline phosphatase and mineralization in marrow osteoprogenitors. J Cell Biochem 68(2):186-194

22. Sama AA, Khan SN, Myers ER, Huang RC, Cammisa FP Jr, Sandhu HS, Lane JM (2004) High-dose alendronate uncouples osteoclast and osteoblast function: a study in a rat spine pseudarthrosis model. Clin Orthop Relat Res 425:135-142

23. Nakashima A, Katagiri T, Tamura M (2005) Cross-talk between Wnt and bone morphogenetic protein 2 (BMP-2) signaling in differentiation pathway of $\mathrm{C} 2 \mathrm{C} 12$ myoblasts. J Biol Chem 280(45):37660-37668 